Article

\title{
Segmentation of Turkish Wine Consumers Based on Generational Cohorts: An Exploratory Study
}

\author{
Arian Seyedimany *(D) and Mehmet Haluk Koksal
}

\begin{abstract}
Department of Business Administration, Faculty of Business and Economics, Eastern Mediterranean University, Famagusta 99628, Cyprus; haluk.koksal@gmail.com

* Correspondence: arian.imani@gmail.com
\end{abstract}

check for updates

Citation: Seyedimany, A.; Koksal, M.H. Segmentation of Turkish Wine Consumers Based on Generational

Cohorts: An Exploratory Study. Sustainability 2022, 14, 3031. https:/ / doi.org/10.3390/su14053031

Academic Editors: Antonietta Baiano and Pasquale Massimiliano Falcone

Received: 18 January 2022

Accepted: 28 February 2022

Published: 4 March 2022

Publisher's Note: MDPI stays neutral with regard to jurisdictional claims in published maps and institutional affiliations.

Copyright: (C) 2022 by the authors. Licensee MDPI, Basel, Switzerland. This article is an open access article distributed under the terms and conditions of the Creative Commons Attribution (CC BY) license (https:// creativecommons.org/licenses/by/ $4.0 /)$.

\begin{abstract}
The purpose of this study is to segment Turkish wine customers based on generational cohorts. It also explores the characteristics of the customers in each group based on wine attributes, information sources, wine consumption, purchase behaviour and socio-economic characteristics. The study's data were collected from the listed mail addresses in some universities, institutes and company websites through a structured online questionnaire. The sample includes 708 respondents. After splitting consumers into three different generational cohorts based on the birth year (Baby Boomers, Generation X and Generation Y), the study clearly profiles the groups by employing principal component analysis, ANOVA and chi-square analyses. After splitting consumers into three groups based on generational cohorts, the study clearly identifies the differences between groups regarding wine attributes, information sources, purchasing and consumption and socio-demographic characteristics. Although there are many studies examining wine consumers in the literature from diverse countries, this is the first study investigating wine consumers based on generational cohorts in Turkey.
\end{abstract}

Keywords: Turkish wine consumers; wine marketing; consumer behaviour; generational cohorts; wine drinking motivations; wine consumption and purchasing behaviour; market segmentation

\section{Introduction}

The globalisation of the world wine industry, consolidation of retail distribution chains, international trade and competition, changes in consumption patterns and new product development initiatives have recently made the world wine market increasingly complex. On the supply side, good-quality wines from new world-producing countries, such as Australia, New Zealand, South Africa, Argentina, Chile and the likes, have started to compete with wines from old world countries. Furthermore, the new world countries developed new production techniques and gained more customer-oriented marketing expertise. The wine industry has become a representation of a monopolistic competition structure characterised by many wineries of different sizes, several wine categories, styles and brands $[1,2]$. The international wine trade has recently been increased by expanding demand mainly in Asian countries, such as China and India, and wine production in these countries is also increasing to meet increasing domestic demand and to satisfy customers in various international markets [3,4]. On the demand side, there have also been tremendous changes in recent decades. The global wine market is extremely fragmented by various customers with different tastes and preferences. Natural and organic wines produced with more sustainable production techniques and fruit-styled, softer wines are preferred by certain customer groups [2,5-8].

As the industry has matured, competition has grown in intensity and complexity, while the preferences and customs associated with wine consumption have changed and become more fragmented with new emerging market segments, such as the Millennials (Generation Y) and Generation Z [3,9-12]. In this new scenario, wine companies should 
focus on forecasting the nature of expansion and increasingly unstable demand, and what their direct and indirect competitors can offer. It is, therefore, imperative to understand and predict changing consumer behaviours [13], apply differentiation marketing strategies and provide the best customer experience to gain customer loyalty in such a competitive environment [14-17].

This study attempts to segment Turkish wine consumers based on generational cohorts. It has become a valuable tool for marketers, since individuals in a cohort are believed to share similar attitudes, beliefs and values. The characteristics of the customers in each group are also explored based on wine attributes, wine consumption and purchase behaviours and socio-economic characteristics. In Turkey, where the majority of the population is Muslim, the study adds to the current wine literature by segmenting wine consumers based on generational cohorts. The rationale behind this objective is to explore the characteristics of wine consumers in a country where drinking alcohol is considered inappropriate by the government and also historically viewed as taboo by most of the population on religious grounds. Thus, this study contributes to the literature by opening a new research area on wine consumption behaviours or other products and foods in countries with strong restrictions and religious influences and establishing a benchmark as a case study.

This study is divided into the following sections. First, the literature review, which includes an overview of wine in Turkey, generational cohort theory, as well conceptual framework and hypothesis, is presented. Second, the research methodology employed in this study is explained. Third, the findings of this study are given in detail. Fourth, the discussion is presented. Fifth, the conclusions and implications for the industry are discussed. Finally, limitations and suggestions for further research are presented.

\section{Literature Review}

\subsection{Wine in Turkey: An Overview}

Historically, viticulture and winemaking are a long-standing tradition in Turkey. The grape was first discovered in the area of the East Anatolia, Georgia and Armenia triangle as early as $6000 \mathrm{BC}$ [18-20]. Wines had a significant effect on the social life of the earliest civilisations in Anatolia, such as the Hittite Empire and Phrygians.

During the Ottoman Empire era (1299-1923), Muslims prohibited wine through Islamic law, and wine production and trade were carried out by non-Muslim minorities [21-23]. Although some heavy sanctions, such as the closure of wine bars and the ban on alcohol sales and consumption, were often enforced, they were relaxed most of the time, since the tax on alcohol sales was one of the important sources of income for the Ottoman Empire treasury [24]. However, even during periods when alcohol was prohibited, it was allowed to be brought in and around Istanbul for non-Muslims to consume at home.

The Muslim population began to engage in wine production only after the establishment of the Republic of Turkey, and the first wine production facilities were established by local manufacturers in 1926 and 1929. In 1925, a state-run company (TEKEL) was nationalised, which carried out and promoted alcohol production with some private small wine producers $[20,25]$. The first winery was opened in Tekirdağ in 1931, followed by Izmir (1935), Tokat, Ürgüp, Gaziantep and Ankara (1943). Due to the monopoly, this was a period when producers had to produce cheap table wines, and only a limited variety of wines was available on the market. Wine production and sales have been engaged in by the private sector since 2003 [26].

Turkey is not considered a major global wine producer, although it is located in a very fertile geographical area and has a favourable climate for grape production. It is ranked sixth in world grape production after China, Italy, the USA, France and Spain [27]. In 2018 , the total area under grape cultivation was $448,000 \mathrm{ha}$, and production was 3.9 million tonnes [27]. However, it is estimated that only $3 \%$ of grape production is used for wine production, amounting to 49.6 million hectolitres. The export value of wine was 9.7 million dollars in 2017, while the quantity of wine exported was almost 2.9 million hectolitres and wine imported was 2.0 million hectolitres [28]. Wine exports are highly concentrated in 
four markets: the Turkish Republic of Northern Cyprus, Belgium, the United Kingdom and Germany. In 2016, the total domestic wine consumption in Turkey was around 51 million litres, and consumption of wine per capita was 0.9 litres, which is very little compared to the main European countries [29]. However, the tastes and preferences of wine customers, especially in big cities, have recently changed due to more interactions with the Western world, and they have begun demanding higher-quality wines.

\subsection{Generational Cohort Theory}

The generational cohort theory was introduced by Karl Mannheim [30] and forged ahead by others [31,32]. The theory suggests that people who experience the same historical, social, cultural, political and economic events during their coming-of-age years (generally between 17 and 23 years old) share common values, preferences and behaviours during their life. A generational cohort is characterised as a group of people who were born during the same period and who go through life together and, therefore, experience similar external events in their late adolescent and early adult years [33,34]. Significant historical events and cultural phenomena lead the generational cohort to form impactful collective memories $[35,36]$. As each generational cohort experiences major events together, they demonstrate common values, attitudes and beliefs through accumulated knowledge and shared experiences, which distinguish one generation cohort from another [37-39]. Segmentation based on generational cohorts has become a very valuable tool for marketers, as individuals in a cohort are believed to share similar values, attitudes and beliefs. In general, studies [40-42] have identified that segmentation based on generational cohorts is richer and more effective than chronological age. Generational cohorts have also been a useful base for segmenting wine consumers and analysing their preferences and behaviours $[9,43,44]$.

\section{Conceptual Framework and Hypothesis}

Studies on drinking behaviour literature have generally focused on the motives behind binge alcohol drinking, the relationship between drinking and establishing status in groups or society in general and building or maintaining social relationships. However, only a few studies [45-47] have attempted to examine wine drinking motivations. These motivations determine how consumers relate to wine by giving it a particular role in their lives and relationships with others.

Previous studies have found different motivations for drinking wine among generational cohorts. Based on a qualitative study by [48], young adults (18-30 years old) are more likely to view wine as socially inclusive, a culturally acceptable commodity purchased and consumed to promote friendship and relationships. A study [49] found that the 18-25-year-old group placed more importance on the 'fun and enjoyment' motivation behind drinking wine. Relaxing was more important for the 26-34-year-old group, while mood enhancement and excitement were less important for the $35+$ year-old group. Previous studies have shown that the potential health benefits of wine are more important to Millennials [50] and Baby Boomers [51]. In one of the studies [52], the results show that wine is preferred by both Generation $X$ and Millennials due to its health benefits and is seen as well suited for socialising. Millennials are interested in wine as the perfect drink for romantic occasions. Based on a study [53], Millennials choose wine because it gives a sophisticated and high social status impression. In a study of young Chinese wine consumers, social communication and body health were chosen for drinking wine [54]. It can, therefore, be proposed that:

Hypothesis 1 (H1). Baby Boomer, Generation X and Millennial wine consumers differ in their motivations to drink wine.

Wine attributes also play an important role in choosing wine. Hall et al. found wine quality to be an important attribute for older generations, such as Generation $X$ 
and Baby Boomers [49]. Qenani-Petrela and Wolf claimed that premium quality is more desirable to Baby Boomers than to Millennials [51]. The grape variety was verified as the less important attribute for younger generation consumers than older ones, according to [49], while, in most recent studies, Millennials are also less interested in grape variety than Generation X and Baby Boomers [10]. Tait et al. indicated that Baby Boomers are willing to pay significantly more for country-of-origin attributes than either Millennials or Generation X consumers [55]. In a study on Italian Millennials, it was reported that higher prices reduced the probability of a wine being chosen [3]. Lategan et al. found that South African Millennials considered branding important, but the region of origin was one of the least important attributes [56]. Based on de Magistris et al. research, Spanish counterparts ascribed more importance to the 'designation of origin', while American Millennials prioritised taste experience [57]. Lategan et al. found that Millennials find information generated by commercial sources (e.g., the label, shelf information, brochures or wine reviews) less important than information from more personal sources, such as family and friends [56]. According to Atkin and Thach, Millennials showed a demonstrably greater preference for gathering information from friends/family and from reading shelf talkers than elders, whereas elders relied more on store personnel, wine stewards and the bottle label [58]. Hence, it can be suggested that:

Hypothesis 2 (H2). Baby Boomer, Generation X and Millennial wine consumers are different based on the wine attributes they consider and the information sources employed.

Wine purchasing and consumption patterns are another key determinant in the segmentation of wine consumers. Millennials and younger consumers tend to drink wine in pubs, bars or restaurants, while older age cohorts, such as Generation X, mainly drink wine at home [59]. According to [51], Baby Boomers were less likely than Generation $X$ and Millennials to purchase wine from liquor stores but more likely than others to buy wines through a wine club. Koksal, however, discovered that Millennials mostly buy wine from supermarkets, while Baby Boomers prefer to purchase it from liquor shops [60]. In Canada [61], it was found that the generations show no differences as far as wine buying from the mainstream distribution outlet categories is concerned. However, the same study indicated that Millennials buy significantly less wine than older consumers from winery tasting rooms and bars/pubs. In the USA, Olsen et al. identified that all generations preferred dry red wine; Millennials, however, had a strong affinity for sweet white wine [62]. Teagle et al. found that younger Australian Millennials (18-24 years old) drink only or mostly white wine compared to older generations [59]. Quester and Smart found that involvement levels increased with age until the above-55 age group [63]. Bruwer and Buller found that wine involvement increases with age until the 35-45-year age group (Generation $X)$ and then slowly begins to decrease [64]. Thach and Chang found that Baby Boomers and older Millennials drink wine more often, but older Millennials actually scored significantly higher than the other generations in drinking wine daily [65]. However, there are studies that identified that Generation $Y$ wine consumers drink and spend less on wine than their Generation $X$ counterparts $[53,59,60]$. Hence, it can be hypothesised that:

Hypothesis 3 (H3). Baby Boomer, Generation X and Millennial wine consumers are different in their wine purchasing patterns and consumption.

Another important factor that influences the wine-choosing process is the socioeconomic differences among different generational cohorts. The qualitative study conducted by [66] confirmed that Millennials perceive champagne and sparkling wines as women's drinks. Ritchie asserted that, although wine buying is considered a traditional male role, more females buy wine [67]. Based on the findings of [60], marital status differentiates in the generational groups but gender does not. Mostly, Generation $\mathrm{Z}$ wine consumers were single, student and earned a low income. Millennials worked either in private or public sectors for the most part, while Generation X and Baby Boomers were 
mostly self-employed. Koksal also found that other generations are mainly married and earn more income than younger wine drinkers [60]. It can, therefore, be proposed that:

Hypothesis 4 (H4). Baby Boomer, Generation X and Millennial wine consumers are different according to their socio-economic characteristics.

\section{Research Methodology}

\subsection{Research Design and the Research Context}

This study is based on qualitative research with a large sample of Turkish wine consumers. An online survey method was used for data collection due to its convenience, low cost and turnaround speed. This method has been employed in previous segmentation studies $[68,69]$. No accurate sampling frame was available for the wine drinkers of Turkey. Therefore, the sampling frame was chosen from some universities, institutes and company websites, and the listed e-mail addresses were used to reach targeted individuals. Before applying a full-scale study, the questionnaire was tested on 28 master's students and faculty members to avoid any problems in the questionnaire, such as unclear wording or misunderstanding. Then, the mail questionnaire was built on Google Form, whereby respondents could access and complete it online after a unique hyperlink was provided via e-mail. The respondents were selected by employing filter questions, such as 'Are you older than 18 years old?', 'Do you drink wine?' and 'Have you bought a bottle of wine in the last month?' The aim of this study was to gather information from around 700 people as the sample size. Therefore, 3000 people were approached, and 708 surveys were collected. Table 1 presents the socio-demographic profiles of the respondents.

Table 1. Sample characteristics.

\begin{tabular}{cc}
\hline Gender & \\
\hline Female & $51.3 \%$ \\
Male & $48.7 \%$ \\
\hline Age & \\
\hline $20-29$ & $12.1 \%$ \\
$30-39$ & $29.7 \%$ \\
$40-49$ & $25.0 \%$ \\
$50-59$ & $16.5 \%$ \\
60 and older & $16.7 \%$ \\
\hline Occupation & \\
\hline Public and private sector employee & $73.3 \%$ \\
Self-employed & $7.7 \%$ \\
Retired & $16.5 \%$ \\
Student, housewife, unemployed & $2.5 \%$ \\
\hline Marital status & \\
\hline Single & $37.1 \%$ \\
Married & $62.0 \%$ \\
\hline Education & \\
\hline Secondary/diploma & $1.8 \%$ \\
University & $35.3 \%$ \\
Master and Ph.D. & $62.9 \%$ \\
\hline Net incomer &
\end{tabular}

Net income per month (\$) 
Table 1. Cont.

\begin{tabular}{cc}
\hline Less than 400 & $1.3 \%$ \\
$400-600$ & $2.3 \%$ \\
More than 600 & $4.4 \%$ \\
$7001-10,000$ & $14.4 \%$ \\
Higher than 10,000 & $77.7 \%$ \\
\hline Total & 708 \\
\hline
\end{tabular}

\subsection{Research Variables}

A questionnaire was formulated to collect the data required for the research. It was available in Turkish and comprised five sections. In the first section, respondents were asked about their agreement level with their wine drinking motivations on a five-point Likert-type scale ranging from 1: Strongly disagree to 5: Strongly agree. The wine drinking motivations construct was prepared through reviewing the literature [70-73]. In the second section, the respondents evaluated wine attributes that influenced them during the selection of wine, such as quality, price, country of origin and taste on a five-point Likert-type scale ranging from 1: Not important at all to 5: Very important. The third section included information sources, such as sales representative, internet and personal experience, on a five-point Likert-type scale ranging from 1: None to 5: Very often. In the fourth section, a short version of the wine involvement scale with four items, measuring the importance, interest and knowledge level of consumers regarding wine on a five-point Likert scale, was adapted from other studies [73-75]. The internal reliability of the involvement scale was 0.88 . In the fifth section of the questionnaire, respondents were asked to answer questions regarding their wine purchasing and consumption behaviour. They included frequency of wine consumption, amount of wine consumption, the monthly budget for wine, preferred wine types and type of outlet where they purchase wine. The last part of the questionnaire included six socio-demographic characteristics of the respondents, including gender, age, marital status, education level, occupation and net monthly income level.

\section{Results}

The data analysis was carried out using SPSS 20 software to pursue the objective of the study. Before analysing the data, exploratory factor analysis (EFA) with varimax rotation was applied to wine drinking motivations. It involves data reduction, as it attempts to represent a set of variables by a smaller number of subsets or factor groups. To have practical significance, items with factor loadings below 0.5 were dropped from the analysis [76]. According to the analysis results, wine drinking motivations were grouped under five headings: enjoyment, coping, socialisation, hedonic and health. Factor analysis explained $66.7 \%$ of the total changes in variations. The Kaiser-Meyer-Olkin statistic (KMO) is the measure of sampling adequacy. Kaiser stated that values greater than 0.5 are acceptable, values between 0.8 and 0.9 are great, and values between 0.9 and 1.0 are superb. For the data, the value of KMO was 0.80, which fell into the range of being great [77]. Bartlett's test of Sphericity, $\chi^{2}$ (136): 4376.203, $p<0.001$ indicated that the correlation between items was sufficient to proceed with factor analysis [78]. Cronbach's alpha $(\alpha)$, which measures the internal reliability of the dimensions, was between 0.71 and 0.87 , which was above 0.7 , the acceptable level for furthering the analysis [79]. Composite reliabilities (CR) were calculated as a more robust measure of reliability in comparison with $(\alpha)$ [80]. The internal consistency is considered satisfactory for all the measurement scales, as composite reliabilities (CR) are higher than 0.7 and higher than Cronbach's alphas for each factor [81]. To check construct validity, the convergent and discriminant validity of each of the scales was tested. All average variance-extracted (AVE) coefficients were above 0.50 , which demonstrates that all the constructs had adequate convergent validity [82].

To check whether the data were free of common method bias, as survey data are usually plagued by this problem, Harman's one-factor test was applied [83]. The results indicated that the data were free of common method bias, as one factor explained only 
$27.02 \%$ of the variance, which was less than $50 \%$ [84]. Table 2 illustrates the factor analysis results based on wine drinking motives.

Table 2. Factor analysis results based on wine drinking motives.

\begin{tabular}{|c|c|c|c|c|c|}
\hline Wine Drinking Motives & $\begin{array}{l}\text { Factor } \\
\text { Loading }\end{array}$ & $\begin{array}{c}\text { Variance Explained } \\
(\%)\end{array}$ & $\alpha$ & CR & AVE \\
\hline Enjoyment & & 27.019 & 0.783 & 0.857 & 0.601 \\
\hline I drink wine because it is delicious & 0.827 & & & & \\
\hline I love the taste of wine & 0.785 & & & & \\
\hline Wine enhances the taste of food & 0.761 & & & & \\
\hline I drink wine because I love its smell & 0.723 & & & & \\
\hline Coping & & 14.686 & 0.774 & 0.820 & 0.534 \\
\hline I drink wine when I am depressed & 0.801 & & & & \\
\hline I drink wine because it improves my mood & 0.738 & & & & \\
\hline I drink wine because it reduces my tension during the day & 0.727 & & & & \\
\hline I drink wine when I feel lonely & 0.650 & & & & \\
\hline Socialising & & 9.460 & 0.736 & 0.806 & 0.513 \\
\hline I drink wine to get closer to others & 0.812 & & & & \\
\hline I drink wine to adapt to the society & 0.746 & & & & \\
\hline I drink wine to show that I know more about it to others & 0.675 & & & & \\
\hline I drink wine to be more romantic & 0.616 & & & & \\
\hline Hedonic & & 8.646 & 0.717 & 0.782 & 0.547 \\
\hline I drink wine to celebrate something & 0.784 & & & & \\
\hline I drink wine to share something special with others & 0.778 & & & & \\
\hline I drink wine to celebrate the thing that I accomplished & 0.649 & & & & \\
\hline Health & & 6.908 & 0.873 & 0.894 & 0.809 \\
\hline I drink wine because it balances my blood circulation & 0.904 & & & & \\
\hline I drink wine for my health benefits & 0.895 & & & & \\
\hline
\end{tabular}

For the purpose of analysis, the generational consumer groups were established by employing globally accepted time periods, including Millennials born between 1980 and 1994; Generation X respondents born between 1965 and 1979; and Baby Boomers born between 1945 and 1964 [85-87]. Thus, Millennials included 296 consumers, who were at the top of the sample with $41.8 \%$ of the sample. Generation X included 294 consumers, who accounted for $41.5 \%$ of the sample. Finally, Baby Boomers comprised 117 consumers, accounting for $16.5 \%$ of the sample. Although the COVID-19 pandemic context and collecting data on Muslims' alcohol usage habits come with the limitation of applying the survey to all social classes, the sample distribution is fairly in line with the distribution of the population of Turkey, since it has a relatively young population $(67.9 \%$ are $15-64$ years old, and $9.7 \%$. are older than 65 years old) [88].

ANOVA analysis and post-hoc analysis (Tukey test) were applied to test whether there was a relationship between customer groups and wine drinking motives. Based on the results, there were differences among generational consumer groups based on all wine drinking motivations. For example, Baby Boomers drink wine for health and socialisation motivations more than other generations. Millennials consume wine for coping and hedonic reasons, whereas Generation X drinks wine for enjoyment motivations more than other generations. Table 3 presents the cluster profiles based on mean scores of wine drinking motivations. 
Table 3. Cluster profiles based on wine drinking motives.

\begin{tabular}{ccccc}
\hline Wine Drinking Motives & Millennials 296 & Generation X 294 & Baby Boomers 117 & F-Value \\
\hline Enjoyment & 3.75 & 3.96 & 3.72 & $6.131^{* *}$ \\
Coping & 2.24 & 1.93 & 1.95 & $9.719^{* * *}$ \\
Socialisation & 1.88 & 1.75 & 2.05 & $6.325^{* *}$ \\
Hedonic & 2.64 & 2.42 & 2.24 & $12.403^{* * *}$ \\
Health & 2.28 & 2.62 & 2.92 & $13.563^{* * *}$ \\
\hline
\end{tabular}

Notes: ${ }^{* * *} p<0.001 ;{ }^{* *} p<0.01$.

In terms of wine attributes, the study results indicated that there were statistically significant differences among the generation groups regarding price, alcohol level, region, grape variety and international awards and medals received. However, quality, cork, bottle, brand, label and packaging did not differentiate the three-generation groups. Based on the information sources used in the selection of wine, the results showed statistical differences among customer generation groups based on customers' friends and colleagues, labels and packages of wines, internet sources and sales people. Table 4 shows the cluster profiles based on mean scores of wine attributes and information sources.

Table 4. Cluster profiles based on wine attributes and information sources.

\begin{tabular}{ccccc}
\hline Wine Attributes & Millennials & Generation X & $\begin{array}{c}\text { Baby } \\
\text { Boomers }\end{array}$ & F-Value \\
\hline Quality & 4.35 & 4.47 & 4.40 & 2.118 \\
Price & 4.07 & 4.01 & 3.69 & $6.801^{* *}$ \\
Cork and bottle & 3.04 & 3.37 & 3.66 & 13.503 \\
Taste & 4.73 & 4.81 & 4.60 & $6.705^{* *}$ \\
Brand & 3.46 & 3.48 & 3.62 & 0.918 \\
Alcohol degree & 2.89 & 3.10 & 3.27 & $4.841^{*}$ \\
Package and label & 2.89 & 2.86 & 3.09 & 1.754 \\
Region & 3.47 & 3.74 & 3.74 & $4.265^{*}$ \\
Grape variety & 3.68 & 4.05 & 3.85 & $7.118^{* *}$ \\
International awards and medals & 2.93 & 3.30 & 2.97 & $6.424^{* *}$ \\
\hline Wine information sources & & & & \\
\hline My own knowledge and experience & 4.02 & 4.01 & 3.92 & 0.437 \\
Friends and colleagues & 3.49 & 3.42 & 3.00 & $7.945^{* * *}$ \\
Family members & 2.46 & 2.71 & 2.54 & 2.467 \\
Label and package & 3.14 & 2.81 & 3.12 & $5.168^{* *}$ \\
Written and visual media & 2.64 & 2.54 & 2.44 & 1.071 \\
Internet & 3.00 & 2.60 & 2.13 & $19.103^{* * *}$ \\
Sales people & 2.33 & 2.18 & 2.01 & $3.029^{*}$ \\
\hline Notes: ${ }^{* * *} p<0.001 ; * * p<0.01 ; * p<0.05$. & & & &
\end{tabular}

To understand whether there were any statistical differences among the three-generation wine groups regarding wine purchasing and consumption behaviours, a chi-square analysis was conducted. Results showed that Baby Boomers drink wine more on special occasions (44.1\%) than Generation X (26.5\%) and Millennials (29.4\%). Generation X, however, drinks wine more once a week $(41.2 \%)$ than other groups. The analysis also revealed that Baby Boomers allocate less than 5 dollars $(25.4 \%)$ per month for wine in comparison with Generation X, which spends 13 and more dollars (55.4\%) and Millennials, who spend between 5 and 12 dollars (47.0\%) per month on wine. In addition, no statistically significant differences were observed among generational consumer groups based on weekly wine consumption and place of wine consumption. Table 5 shows the cluster profiles based on wine consumption behaviours. 
Table 5. Cluster profiles based on wine consumption behaviours.

\begin{tabular}{|c|c|c|c|c|}
\hline Wine Consumption Behaviour & Millennials & Generation X & Baby Boomers & $x^{2}$ Value \\
\hline Frequency of drinking & & & & $40.717^{* * *}$ \\
\hline Special occasions & $87(29.4)$ & $78(26.5)$ & $52(44.1)$ & \\
\hline Once a month & $94(31.8)$ & $60(20.4)$ & $11(9.3)$ & \\
\hline Once a week & $99(33.4)$ & $121(41.2)$ & $39(33.1)$ & \\
\hline Once a day & $16(5.4)$ & 35 (11.9) & $16(13.6)$ & \\
\hline Weekly wine consumption & & & & 11.941 \\
\hline Less than one bottle & $219(74.0)$ & $195(66.3)$ & $84(71.2)$ & \\
\hline $1-2$ bottles & $67(22.6)$ & $90(30.6)$ & $25(21.2)$ & \\
\hline 3-4 bottles & $7(2.4)$ & $4(1.4)$ & $5(4.2)$ & \\
\hline More than four bottles & $3(1.0)$ & $5(1.7)$ & $4(3.4)$ & \\
\hline Monthly wine budget & & & & $35.587^{* * *}$ \\
\hline Less than $\$ 5$ & $58(19.6)$ & $51(17.3)$ & $30(25.4)$ & \\
\hline$\$ 5-\$ 12$ & $139(47.0)$ & $80(27.2)$ & $38(32.2)$ & \\
\hline$\$ 13$ and more & $99(33.4)$ & $163(55.4)$ & $50(42.4)$ & \\
\hline Consumption place & & & & 4.551 \\
\hline Home & $233(80.3)$ & $218(74.7)$ & $92(80.7)$ & \\
\hline Restaurants & $50(17.2)$ & $64(21.9)$ & $21(18.4)$ & \\
\hline Pub, Café and traditional Turkish bar & $7(2.4)$ & $10(3.4)$ & $1(0.9)$ & \\
\hline
\end{tabular}

Notes: ${ }^{* * *} p<0.001$. Data in the parentheses show relative size of the groups as $\%$.

Statistically significant differences among three-generation wine consumer groups regarding wine purchasing behaviour were also investigated. According to the chi-square analysis, there were statistically significant differences among the generation cohorts for wine involvement $\left(\chi^{2}=17.502, p<0.01\right)$. Compared to Baby Boomers $(27.1 \%)$ and Millennials $(24.7 \%)$, Generation $X$ consumers $(36.4 \%)$ were highly involved with wine. Almost half of Baby Boomers (48.3\%) and Millennials (44.6\%) reported that their involvement level with wine was low. Based on the type of wine, all three groups favour mostly red wine, but Baby Boomers (91.5\%) preferred red wine more than Generation X (78.2\%) and Millennials $(66.6 \%)$. However, compared to Baby Boomers, Generation X and Millennials had more inclination to try other types of wine. Three-generation consumer groups mainly buy wines from supermarkets. Generation X (20.1\%) and Baby Boomers (21.2\%) purchase their wines from wineries more than Millennials (11.1\%). The study results indicated that Turkish wine customers prefer to purchase Turkish wine, probably due to familiarity and availability. However, Millennials tend to try wine from different countries. Table 6 shows the cluster profiles based on wine purchasing behaviours.

Table 6. Cluster profiles based on wine purchasing behaviours.

\begin{tabular}{|c|c|c|c|c|}
\hline Wine Purchasing Behaviour & Millennials & Generation X & Baby Boomers & $x^{2}$ Value \\
\hline Involvement with wine & & & & $17.502 * *$ \\
\hline High & $73(24.7)$ & $107(36.4)$ & $32(27.1)$ & \\
\hline Moderate & $91(30.7)$ & $94(32.0)$ & $29(24.6)$ & \\
\hline Low & $132(44.6)$ & $93(31.6)$ & $57(48.3)$ & \\
\hline Type of wine & & & & $32.823^{* * *}$ \\
\hline Red & $197(66.6)$ & $230(78.2)$ & $108(91.5)$ & \\
\hline White & $48(16.2)$ & $33(11.2)$ & $8(6.8)$ & \\
\hline Rose & $47(15.9)$ & $28(9.5)$ & $1(0.8)$ & \\
\hline Champagne, brandy and port & $4(1.4)$ & $3(1.0)$ & $1(0.8)$ & \\
\hline
\end{tabular}


Table 6. Cont.

\begin{tabular}{cccc}
\hline Wine Purchasing Behaviour & Millennials & Generation $\mathbf{X}$ & Baby Boomers \\
\hline Type of outlets & & & $\chi^{2}$ Value \\
\hline Grocery shops & $211(71.3)$ & $172(58.5)$ & $64(54.2)$ \\
Liquor shops & $37(12.5)$ & $45(15.3)$ & $20(16.9)$ \\
Wineries & $33(11.1)$ & $59(20.1)$ & $25(21.2)$ \\
Online & $5(1.7)$ & $2(0.7)$ & $0(0.0)$ \\
Others & $8(2.7)$ & $10(3.4)$ & $3(2.5)$ \\
\hline Country of origin & & & $99(84.6)$ \\
Turkey & $206(69.8)$ & $215(74.9)$ & $5(4.3)$ \\
France & $33(11.2)$ & $28(9.8)$ & $4(3.4)$ \\
Italy & $35(11.9)$ & $23(8.0)$ & $4(3.4)$ \\
Spain & $6(2.0)$ & $14(2.4)$ & $5(4.3)$ \\
\hline
\end{tabular}

Notes: ${ }^{* * *} p<0.001 ;{ }^{* *} p<0.01 ;{ }^{*} p<0.05$. Data in the parentheses show relative size of the groups as $\%$.

Based on the chi-square analysis results, all socio-demographic variables differentiated the customer groups. Millennials included more females (69.3\%) and Baby Boomers included more males (89.8\%). Most of the Millennials (56.4\%) were single compared to Generation X (28.2\%) and Baby Boomers (11.0\%). More than half of Generation X (67.7\%) and Millennial customers (69.3\%) were master's and PhD degree holders. Millennials $(91.9 \%)$ and Generation X (76.9\%) contained more private and public sector employees. Baby Boomers, however, comprised retired people (71.2\%). Table 7 shows the differences among generational groups based on socio-demographic characteristics.

Table 7. Cluster profiles based on socio-demographic characteristics.

\begin{tabular}{|c|c|c|c|c|}
\hline & Millennials & Generation X & Baby Boomers & $x^{2}$ Value \\
\hline Gender & & & & $118.419^{* * *}$ \\
\hline Female & $205(69.3)$ & $146(49.7)$ & $12(10.2)$ & \\
\hline Male & $91(30.7)$ & $148(50.3)$ & $106(89.8)$ & \\
\hline Marital status & & & & $91.603^{* * *}$ \\
\hline Single & $167(56.4)$ & $83(28.2)$ & $13(11.0)$ & \\
\hline Married & $129(43.6)$ & $211(71.8)$ & $105(89.0)$ & \\
\hline Education & & & & $52.975^{* * *}$ \\
\hline Secondary & $5(1.7)$ & $7(2.4)$ & $1(0.8)$ & \\
\hline University & $86(29.1)$ & $88(29.9)$ & $76(64.4)$ & \\
\hline Master's and Ph.D. & 205 (69.3) & 199 (67.7) & $41(34.7)$ & \\
\hline Net income level per month (\$) & & & & $21.474^{* * *}$ \\
\hline Less than 400 & $30(10.1)$ & $18(6.1)$ & $8(14.3)$ & \\
\hline $400-600$ & $61(20.6)$ & $29(9.9)$ & $12(10.2)$ & \\
\hline More than 600 & $205(69.3)$ & $247(84.0)$ & $98(83.1)$ & \\
\hline Occupation & & & & $339.809^{* * *}$ \\
\hline Student, housewife, unemployed & $9(3.0)$ & $9(3.1)$ & $0(0.0)$ & \\
\hline Retired & $0(0.0)$ & $33(11.2)$ & $84(71.2)$ & \\
\hline Private/public sector employees & $272(91.9)$ & $226(76.9)$ & $21(17.8)$ & \\
\hline Self-employed & $15(5.1)$ & $26(8.8)$ & $13(11.0)$ & \\
\hline
\end{tabular}

Notes: ${ }^{* * *} p<0.001$. Data in the parentheses show relative size of the groups as $\%$.

\section{Discussion}

In this study, Turkish wine consumers were grouped into three cohorts based on their generation: Baby Boomers, Generation X and Millennials. Some similarities and differences were determined among these generational wine consumer groups regarding 
wine drinking motivations, wine attributes, wine consumption and purchasing behaviours and socio-economic characteristics.

Baby Boomers consumed wine for socialisation and considered wine a healthy beverage, especially for preventing heart and circulatory diseases, obesity, dementia and digestion problems. It also provides longevity and a better quality of life. This finding was highlighted by Refs. [60,65]. Baby Boomers regarded the taste and quality of wine as the most important wine attributes. However, they scored higher on region or appellation of wine and alcohol levels than the other generational groups. They relied mostly on their own experience, knowledge, label and package of wine in the buying process. They mostly drank wine on special occasions and once a week, although this group consumed wine once a day more than other groups. This is similar to the findings of Ref. [65]. Baby Boomers spent between 5 and 13 or more dollars on wine. More than half of them reported that they were either very involved or moderately involved with wine. They predominantly preferred red wine and went for local wines. They chose to buy wines from wineries and liquor shops more than the other generational groups, although more than half of them purchased wine from supermarkets. They were mostly married male senior citizens with a monthly net income of more than 600 dollars. This generation is important to wineries and wine companies regarding the frequency and amount of wine drinking. Managers targeting this group should emphasise the region or appellation of wine besides taste and quality and recognise the importance of wine packaging and labelling in communication. They should also diversify their distribution channels by concentrating more on wineries and special liquor shops, including activities such as winery visits and tasting rooms.

Generation X customer group drank wine for enjoyment motivation and regarded the taste and quality of wine, grape variety and international awards and medals as the most essential wine attributes. They depended on their own experience, knowledge and suggestions from their friends and colleagues. They mostly drank wine once a week and on special occasions and spent 13 and more dollars in a month. As Wolf et al. indicated, Generation $\mathrm{X}$ and Baby Boomers are the generational consumer groups that spend more money on wine than other groups [44]. They scored more on high-level involvement than other generational groups. They mostly preferred red wine and purchased wine from supermarkets, wineries and liquor shops. They mostly chose to consume local wines. This group was equally distributed between male and female consumers. They were mostly married, as well as public and private employees, earning more than 600 dollars in monthly net income. Companies deciding to serve this generational group should stress grape variety and the international awards and medals they received. This group of consumers was highly involved with wine and wanted to know more about it; therefore, they enjoyed talking to very professional sales people. To attract this group, wineries and wine companies might organise wine tasting events and invite wine experts and writers to speak.

This study's findings indicated that Millennials consumed wine for enjoyment reasons. However, their coping and hedonic motivations were higher than those of the other two groups. Previous studies concluded that Millennials consume wine for hedonic and fun motivations $[59,89]$. This group of consumers considered taste and quality the most important attributes. Interestingly, they emphasised the price of wine more than other generational groups when purchasing wine. This finding parallels the results of other studies $[11,44,60]$. They relied on their own knowledge, experience and suggestions from their friends and colleagues in their buying decision process. They mostly drank wine once a week or once a month and spent between 5 and 13 dollars on wine per month. It appears that they were not much involved with wine. They mostly preferred drinking red wine. However, this group had the highest tendency to try other types of wine and wine from different countries. Previous studies observed that Millennials are open-minded regarding trying different types of wines to establish their taste and choose to purchase from various outlets when purchasing wine $[9,90]$. They mainly purchased wines from supermarkets. The majority of this group comprised females, with almost equally distributed single and 
married consumers. They were mostly public and private sector employees, earning 600 or more dollars per month. This generational group should not be ignored, since it seems to be the largest portion of the market. They gradually establish their wine tastes and purchasing patterns. Companies might offer them unsophisticated and basic wines, since they focus on the price of wine. Companies targeting this group should identify and target opinion leaders in their promotional activities, since they make their decisions through their friends and colleagues.

\section{Conclusions}

\subsection{Theoretical Contributions}

From an academic viewpoint, this study has several implications. The study contributes to the existing wine literature by segmenting wine consumers based on generational cohorts in Turkey, where most of the population is Muslim. Therefore, it enlarges a much-needed line of research to uncover an emerging phenomenon, such as the consumption of products and foods that can be considered taboo by a large part of the population. It also adds to the wine purchasing and consumption literature with its research efforts to determine how generational cohorts interact with other consumer behaviour variables in different wine consumer segments.

\subsection{Managerial Implications}

From a managerial perspective, this study could be helpful for marketers to better understand wine consumer segments. It provides significant insights into marketers planning to operate in Turkey, as little related research has been conducted in the region. Understanding the characteristics of each marketing segment, managers can design more accurate and better targeted marketing strategies for each consumer group. Although markets in the region are very profitable, culture, specifically religion, still plays an important role in the day-to-day activities of its people.

\subsection{Limitations and Directions for Future Research}

This study has some limitations. The findings of this study cannot be generalised, as it is limited to wine consumption in Turkey. More research will be needed in other countries to reach more conclusive results. Another limitation of this study is its sampling bias. The monthly net income and education levels among the total sample are high, as the data were gathered through an online survey targeting respondents from universities, institutes and organisations. It is recommended that future studies consider more rigorous sampling with a close number of participants from different income levels and educational backgrounds.

Younger generations, such as Generation $\mathrm{Z}$ wine consumers, were not included as a generation cohort in this study. As Generation $\mathrm{Z}$ can be the largest generation of the world's population, studying wine drinking and purchasing preferences and behaviours of this consumer group is crucial and should be examined.

Further studies should also examine the wine consumption behaviours of tourists. Turkey is one of the most visited tourism destinations globally, with its history, climate, nature, culture and food. It also has an old traditional and rooted vinery culture.

This study attempted to segment Turkish wine consumers only based on their generational cohorts; future studies could use other variables to segment Turkish wine consumers, such as their level of involvement, level of experience and customer value co-creation behaviour [91] in wine.

Marketing can play a significant role in wine companies' success. However, wine and alcoholic beverages are restricted by law concerning sales, advertising and promotion in some countries, such as Turkey. Culture, specifically religion, plays an important role in the purchasing and consumption of wine. Therefore, investigating the specific marketing strategies and policies used in such circumstances could expand the scope of wine research. 
Author Contributions: Conceptualisation, A.S. and M.H.K.; methodology, A.S. and M.H.K.; software, A.S. and M.H.K.; validation, M.H.K.; formal analysis, A.S. and M.H.K.; investigation, A.S. and M.H.K.; resources, A.S. and M.H.K.; data curation, A.S. and M.H.K.; writing-original draft preparation, A.S.; writing-review and editing, M.H.K.; supervision, M.H.K.; project administration, A.S. All authors have read and agreed to the published version of the manuscript.

Funding: This research received no external funding.

Institutional Review Board Statement: Ethical review and approval were waived for this study, due to the fact that interactions were only conducted via an online survey, and there was no human interaction.

Informed Consent Statement: Informed consent was obtained from all subjects involved in the study.

Data Availability Statement: The data presented in this study are available on request from the authors of this study.

Conflicts of Interest: The authors declare no conflict of interest.

\section{References}

1. Galati, A.; Crescimanno, M.; Coelho, A.; Maizza, A. Recent trends in the wine consumers' behaviour and need for effective marketing strategies. Br. Food J. 2020, 122, 2361-2369. [CrossRef]

2. Ferreira, C.; Rebelo, J.; Lourenco-Gomes, L.; Correia, E.; Baumert, P.; Plumejeaud, C. Consumer preferences and purchasing rationales for wine: A multivariate data analysis. New Medit 2020, 19, 133-144. [CrossRef]

3. Nassivera, F.; Gallenti, G.; Troiano, S.; Marangon, F.; Cosmina, M.; Bogoni, P.; Campisi, B.; Carzedda, M. Italian millennials' preferences for wine: An exploratory study. Br. Food J. 2020, 122, 2403-2423. [CrossRef]

4. Mariani, A.; Pomarici, E.; Boatto, V. The international wine trade: Recent trends and critical issues. Wine Econ. Policy 2020, 1, 24-40. [CrossRef]

5. Fabbrizzi, S.; Sottini, V.A.; Cipollaro, M.; Menghini, S. Sustainability and natural wines: An exploratory analysis on consumers. Sustainability 2021, 13, 7645. [CrossRef]

6. Merlino, V.M.; Fracassetti, D.; Di Canito, A.; Pizzi, S.; Borra, D.; Giuggioli, N.R.; Vigentini, I. Is the consumer ready for innovative fruit wines? Perception and acceptability of young consumers. Foods 2021, 10, 1545. [CrossRef]

7. Gallenti, G.; Troiano, S.; Marangon, F.; Bogoni, P.; Campisi, B.; Cosmina, M. Environmentally sustainable versus aesthetic values motivating millennials' preferences for wine purchasing: Evidence from an experimental analysis in Italy. Agric. Food Econ. 2019, 7, 12. [CrossRef]

8. Castellini, A.; Mauracher, C.; Troiano, S. An overview of the biodynamic wine sector. Int. J. Wine Res. 2017, 9, 1-11. [CrossRef]

9. Thach, L.; Riewe, S.; Camillo, A. Generational cohort theory and wine: Analyzing how gen Z differs from other American wine consuming generations. Int. J. Wine Bus. Res. 2021, 33, 1-27. [CrossRef]

10. Lembke, S.; Cartier, L. Wine consumers in British Columbia, Canada towards understanding how Millennials differ from previous generations. Int. J. Wine Bus. Res. 2020, 32, 441-455. [CrossRef]

11. Castellini, A.; Samoggia, A. Millennial consumers' wine consumption and purchasing habits and attitude towards wine innovation. Wine Econ. Policy 2018, 7, 128-139. [CrossRef]

12. Wiedmann, K.-P.; Behrens, S.; Klarmann, C.; Hennigs, N. Customer value perception: Cross-generational preferences for wine. Br. Food J. 2014, 116, 1128-1142. [CrossRef]

13. Mirica, C.O. The behavioral economics of decision making: Explaining consumer choice in terms of neural events. Econ. Manag. Financ. Mark. 2019, 14, 16-22.

14. Ellis, E.; Caruana, A. Consumer wine knowledge: Components and segments. Int. J. Wine Bus. Res. 2018, 30, 277-291. [CrossRef]

15. Schaufele, I.; Pashkova, D.; Hamm, U. Which consumers opt for organic wine and why? An analysis of the attitude-behaviour link. Br. Food J. 2018, 120, 1901-1914. [CrossRef]

16. Iaia, L.; Maizza, A.; Fait, M.; Scorrano, P. Origin based agro-food products: How to communicate their experiential value online? Br. Food J. 2016, 118, 1845-1856. [CrossRef]

17. Velikova, N.; Howell, R.D.; Dodd, T. The development of an objective wine, knowledge scale: The item response theory approach. Int. J. Wine Bus. Res. 2015, 27, 103-124. [CrossRef]

18. Kayikcioğlu, S.; Arikan, U. An overlook to world wine industry. Press Acad. Procedia 2020, 1, 219-223. [CrossRef]

19. Turker, N.; Alaeddinoglu, F. From wine production to wine tourism experience: The case of Anatolia, Turkey. J. Tour. Gastron. Stud. 2016, 4, 25-37. [CrossRef]

20. Özay, A.; Akyol, A.; Azabağaoğlu, M.O. The history and development of the Turkish wine industry. Int. J. Wine Mark. 2005, 17, 62-69. [CrossRef]

21. Matthee, R. Alcohol in the Islamic Middle East: Ambivalence and ambiguity. Past Present 2014, 222 (Suppl. S9), 9100-9125. [CrossRef]

22. Özdemir, D. Turkey's Arduous Journey from Vine to Wine: Why Can a Country, with the Fourth-Largest Vineyard in the World, Not Make Wine from Its Grapes? Working Papers; American Association of Wine Economics: New York, NY, USA, 2013; p. 164655. [CrossRef] 
23. Yapucu, O.P. Wine Production and Consumption in the Ottoman Empire. Olive Oil and Wine Production in Eastern Mediterranean during Antiquity International Symposium; Urla: Izmir, Turkey, 2011; pp. 17-19.

24. Koyuncu, D.T.; Tabakoglu, A. Alcohol consumption in Ottoman Istanbul according to Zecriye tax records: 1792-1828. Tüketici Ve Tüketim Araştırmaları Derg. 2019, 11, 191-225.

25. Ribeiro, J.D.; Ribeiro, D.C.; Duarte, J.S. A legacy of grape: A socio-cultural and spatial analysis of Ankara's wine production history. J. Ank. Stud. 2020, 8, 215-251. [CrossRef]

26. Buzrul, S. Türkiye'nin Şarap Sektörü. In Proceedings of the 8 Bağcılık ve Teknolojileri Sempozyumu, Konya, Turkey, 1 September 2013; pp. 25-28.

27. OIV (International Organisation of Vine and Wine Intergovernmental Organisation). Available online: https:/ / www.oiv.int/ public/medias/6782/oiv-2019-statistical-report-on-world-vitiviniculture.pdf (accessed on 1 August 2021).

28. Republic of Turkey Ministry of Trade. Available online: https:/ /www.trade.gov.tr/data/5b8fd55613b8761f041fee87/Wine.pdf (accessed on 6 August 2021).

29. OIV (International Organisation of Vine and Wine Intergovernmental Organisation). Available online: https://www.oiv.int/en/ statistiques $/$ ? year $=2016 \&$ countryCode=TUR (accessed on 29 August 2021).

30. Mannheim, K. The problem of generations. In Essays on the Sociology of Knowledge; Kecskemeti, P., Ed.; Oxford University Press: New York, NY, USA; Oxford, UK, 1952; Volume 32, pp. 276-322.

31. Strauss, W.; Howe, N. The Fourth Turning: An American Prophecy; Broadway: New York, NY, USA, 1997.

32. Inglehart, R. Modernization and Post Modernization: Cultural, Economic, and Political Change in Societies; Princeton University Press: Princeton, NJ, USA, 1997. [CrossRef]

33. Rahulan, M.; Troynikov, O.; Watson, C.; Janta, M.; Senner, V. Consumer behavior of generational cohorts for compression sportswear. J. Fash. Mark. Manag. Int. J. 2015, 19, 87-104. [CrossRef]

34. Schewe, C.D.; Meredith, G.E. Segmenting global markets by generational cohorts: Determining motivations by age. J. Consum. Behav. 2004, 4, 51-63. [CrossRef]

35. Dencker, J.C.; Joshi, A.; Martocchio, J.J. Towards a theoretical framework linking generational memories to workplace attitudes and behaviors. Hum. Resour. Manag. Rev. 2008, 18, 180-187. [CrossRef]

36. Motta, P.C.; Schewe, C. Are marketing management decisions shaped during one's coming of age? Manag. Decis. 2008, 46, 1096-1110. [CrossRef]

37. Thompson, K.H.; Ellis, D.; Soni, S.; Paterson, S. Attributes influencing clothing store choice for an emerging market's generation $\mathrm{Y}$ twixter customers. Int. Rev. Retail. Distrib. Consum. Res. 2018, 28, 157-173. [CrossRef]

38. Carpenter, J.; Moore, M.; Doherty, A.M.; Alexander, N. Acculturation to the global consumer culture: A generational cohort comparison. J. Strateg. Mark. 2012, 20, 411-423. [CrossRef]

39. Motta, P.C.; Rossi, M.; Schewe, C.D. Generational marketing: Exploring cohort-programmed values and their implications on cross-cultural variations in consumer behaviour between Brazil and United States. Rev. Port. De Mark. 2002, 6, 11-21.

40. Ting, H.; Lim, T.-Y.; de Run, E.C.; Koh, H.; Sahdan, M. Are we Baby Boomers, Gen X and Gen Y? A qualitative inquiry into generation cohorts in Malaysia. Kasetsart J. Soc. Sci. 2018, 39, 109-115. [CrossRef]

41. Chaney, D.; Touzani, M.; Slimane, K.B. Marketing to the (new) generations: Summary and perspectives. J. Strateg. Mark. 2017, 25, 179-189. [CrossRef]

42. Parment, A. Generation Y vs. Baby boomers: Shopping behavior, buyer involvement and implications for retailing. J. Retail. Consum. Serv. 2013, 20, 189-199. [CrossRef]

43. LaTour, K.A.; Joy, A.; Noujeim, R. Developing wine appreciation for new generations of consumers. Cornell Hosp. Q. 2021, 62, 337-345. [CrossRef]

44. Wolf, M.; Higgins, L.M.; Wolf, M.J.; Qenani, E. Do generations matter for wine segmentation? J. Wine Res. 2018, 29, 177-189. [CrossRef]

45. Gustavsena, G.W.; Rickertsen, K. Motivation for drinking wine. J. Wine Econ. 2020, 15, 378-385. [CrossRef]

46. New Study Explores Motivations and Behaviors of U.S. Wine Consumers before and during COVID-19 Lockdown. Available online: https: / / www.winebusiness.com/news/?go=getArticle\&dataId=232120 (accessed on 1 August 2021).

47. Moran, C.C.; Saliba, A.J. Reasons for drinking wine and other beverages-comparison across motives in older adults. Int. J. Wine Res. 2012, 4, 25-32. [CrossRef]

48. Ritchie, C. Young adult interaction with wine in the UK. Int. J. Contemp. Hosp. Manag. 2011, 23, 99-114. [CrossRef]

49. Hall, J.; Binney, W.; Barry O'Mahony, G. Age related motivational segmentation of wine consumption in a hospitality setting. Int. J. Wine Mark. 2004, 16, 29-43. [CrossRef]

50. Chang, K.; Thach, M.; Olsen, J. Wine and health perceptions: Exploring the impact of gender, age and ethnicity on consumer perceptions of wine and health. Wine Econ. Policy 2016, 5, 105-113. [CrossRef]

51. Qenani-Petrela, E.; Wolf, M.; Zuckerman, B. Generational differences in wine consumption. J. Food Distrib. Res. 2007, 38, 119-127.

52. Chivu-Draghia, C.; Antoce, A. Understanding consumer preferences for wine: A comparison between millennials and generation X. Sci. Pap. Ser. Manag. Econ. Eng. Agric. Rural. Dev. 2016, 16, 75-84.

53. Chrysochou, P.; Krystallis, A.; Mocanu, A.; Lewis, R.L. Generation Y preferences for wine: An exploratory study of the US market applying the best-worst scaling. Br. Food J. 2012, 114, 516-528. [CrossRef] 
54. Li, J.-G.; Jia, J.-R.; Taylor, D.; Bruwer, J.; Li, E. The wine drinking behaviour of young adults: An exploratory study in China. Br. Food J. 2011, 113, 1305-1317. [CrossRef]

55. Tait, P.; Saunders, C.; Dalziel, P.; Rutherford, P.; Driver, T.; Guenther, M. Comparing generational preferences for individual components of sustainability schemes in the Californian wine market. Appl. Econ. Lett. 2020, 27, 1091-1095. [CrossRef]

56. Lategan, B.; Pentz, C.; du Preez, R. Importance of wine attributes: A South African Generation Y perspective. Br. Food J. 2017, 119, 1536-1546. [CrossRef]

57. De Magistris, T.; Groot, E.; Gracia, A.; Miguel Albisu, L. Do Millennial generation's wine preferences of the "New World" differ from the "Old World"? A pilot study. Int. J. Wine Bus. Res. 2011, 23, 145-160. [CrossRef]

58. Atkin, T.; Thach, L. Millennial wine consumers: Risk perception and information search. Wine Econ. Policy 2012, 1, 54-62. [CrossRef]

59. Teagle, J.; Mueller, S.; Lockshin, L. How do millennials' wine attitudes and behaviors differ from other generations? In Proceedings of the 5th International Academy of Wine Business Research Conference, Auckland, New Zealand, 8-10 February 2010.

60. Koksal, M.H. Differences among baby boomers, Generation X, Millennials, and Generation Z wine consumers in Lebanon: Some perspectives. Int. J. Wine Bus. Res. 2019, 31, 456-472. [CrossRef]

61. Bruwer, J.; Lesschaeve, I.; Campbell, B. Consumption dynamics and demographics of Canadian wine consumers: Retailing insights from the tasting room channel. J. Retail. Consum. Serv. 2012, 19, 45-58. [CrossRef]

62. Olsen, J.; Thach, L.; Nowak, L. Wine for my generation: Exploring how US wine consumers are socialized to wine. J. Wine Res. 2007, 18, 1-18. [CrossRef]

63. Quester, P.; Smart, J.G. The influence of consumption situation and product involvement over consumers' use of product attributes J. Consum. Mark. 1998, 15, 220-238. [CrossRef]

64. Bruwer, J.; Buller, C. Product involvement, brand loyalty, and country-of-origin brand preferences of Japanese wine consumers J. Wine Res. 2013, 24, 38-58. [CrossRef]

65. Thach, L.; Chang, K. Wine generations: A new survey looks at consumer wine preferences. Vineyard Winery Manag. 2016, 42, 124-128.

66. Charters, S.; Velikova, N.; Ritchie, C.; Fountain, J.; Thach, L.; Dodd, T.H.; Fish, N.; Herbst, F.; Terblanche, N. Generation Y and sparkling wines: A cross-cultural perspective. Int. J. Wine Bus. Res. 2011, 23, 161-175. [CrossRef]

67. Ritchie, C. The culture of wine buying in the UK off-trade. Int. J. Wine Bus. Res. 2009, 21, 194-211. [CrossRef]

68. Bruwer, J.; Roediger, B.; Herbst, F. Domain-specific market segmentation: A wine-related lifestyle (WRL) approach. Asia Pac. J. Mark. Logist. 2017, 29, 4-26. [CrossRef]

69. Brunner, T.; Siegrist, M. Lifestyle determinants of wine consumption and spending on wine. Int. J. Wine Bus. Res. 2011, 23, 210-222. [CrossRef]

70. Thach, L.; Olsen, J. Luxury wine: Analyzing motivations of luxury wine buyers in the US market. Appl. Stud. Agribus. Commer 2019, 13, 51-58. [CrossRef]

71. Palma, D.; Cornejo, C.; Ortúzar, J.D.; Rizzi, L.I.; Casaubon, G. Tell me why you like to drink wine: Drinking motivations as a basis for market segmentation. In Proceedings of the 8th AWBR International Conference, Geisenheim, Germany, 18-30 June 2014.

72. Mezquita, L.; Stewart, S.H.; Ibáñez, M.I.; Ruipérez, M.A.; Villa, H.; Moya, J.; Ortet, G. Drinking motives in clinical and general populations. Eur. Addict. Res. 2011, 17, 250-261. [CrossRef]

73. Nella, A.; Christou, E. Segmenting wine tourists on the basis of involvement with wine. J. Travel Tour. Mark. 2014, 31, 783-798. [CrossRef]

74. Schaefer, R.; Olsen, J.; Thach, L. Exploratory wine consumer behaviour in a transitional market: The case of Poland. Wine Econ. Policy 2018, 7, 54-64. [CrossRef]

75. Calvo-Porral, C.; Ruiz-Vega, A.; Levy-Mangin, J.-P. The influence of consumer involvement in wine consumption-elicited emotions. J. Int. Food Agribus. Mark. 2019, 31, 128-149. [CrossRef]

76. Hair, J.; Black, B.; Babin, B.; Anderson, R. Multivariate Data Analysis; Pearson Education: London, UK, 2010.

77. Kaiser, H.F. An index of factor simplicity. Psychometrika 1974, 39, 31-36. [CrossRef]

78. Bartlett, M.S. The statistical conception of mental factors. Br. J. Psychol. 1937, 28, 97-104. [CrossRef]

79. Cortina, J.M. What is coefficient alpha? An examination of theory and applications. J. Appl. Psychol. 1993, 78, 98. [CrossRef]

80. Nunnally, J.; Bernstein, I. Psychometric Theory; McGraw-Hill: New York, NY, USA, 1994.

81. Peterson, R.A.; Kim, Y. On the relationship between coefficient alpha and composite reliability. J. Appl. Psychol. 2013, 98, 194. [CrossRef]

82. Fornell, C.; Larcker, D.F. Evaluating structural equation models with unobservable variables and measurement error. J. Mark. Res. 1981, 18, 39-50. [CrossRef]

83. Harman, H.H. Modern Factor Analysis; University of Chicago Press: Chicago, IL, USA, 1976.

84. Podsakoff, P.M.; MacKenzie, S.B.; Lee, J.Y.; Podsakoff, N.P. Common method biases in behavioral research: A critical review of the literature and recommended remedies. J. Appl. Psychol. 2003, 88, 879. [CrossRef]

85. Eger, L.; Komárková, L.; Egerová, D.; Mičík, M. The effect of COVID-19 on consumer shopping behaviour: Generational cohort perspective. J. Retail. Consum. Serv. 2021, 61, 102542. [CrossRef]

86. Kamenidou, I.E.; Stavrianea, A.; Bara, E.Z. Generational differences toward organic food behavior: Insights from five generational cohorts. Sustainability 2020, 12, 2299. [CrossRef] 
87. Marjanen, H.; Kohijoki, A.M.; Saastamoinen, K.; Engblom, J. Old dogs learning new tricks? The effect of age and generation on shopping behaviour. Int. Rev. Retail. Distrib. Consum. Res. 2019, 29, 549-567. [CrossRef]

88. Türkiye Istatistik Kurumu (TÜİK). Available online: https:/ / data.tuik.gov.tr/Bulten/Index?p=The-Results-of-Address-BasedPopulation-Registration-System-2021-45500 (accessed on 7 February 2022).

89. Kennett-Hensel, P.; Neeley, C.; Min, K. Uncorking the mystery of marketing wine to generation Y: Lessons from consumer psychology. Mark. Manag. J. 2011, 21, 54-69.

90. Fountain, J.; Lamb, C. Generation $\mathrm{Y}$ as young wine consumers in New Zealand: How do they differ from generation X? Int. J. Wine Bus. Res. 2011, 23, 107-124. [CrossRef]

91. Meilhan, D. Customer value co-creation behavior in the online platform economy. J. Self-Gov. Manag. Econ. 2019, 7, 19-24. 